Article

\title{
Long Term Spatiotemporal Variability in Rainfall Trends over the State of Jharkhand, India
}

\author{
Shonam Sharma * and Prasoon Kumar Singh \\ Department of Environmental Science and Engineering, Indian Institute of Technology \\ (Indian School of Mines) Dhanbad, Jharkhand Pin-826004, India; singh.prasoon910@gmail.com \\ * Correspondence: shonamsharma@ese.ism.ac.in \\ Academic Editor: Yang Zhang \\ Received: 6 October 2016; Accepted: 24 February 2017; Published: 2 March 2017
}

\begin{abstract}
The current study was conducted to examine the impact of climate change on rainfall in Jharkhand state of India. It deals with the analysis of the historical spatiotemporal variability of rainfall on the annual, seasonal and monthly scale in 18 districts of the state Jharkhand over a period of 102 years (1901-2002). Mann-Kendall trend test and Sen's slope method were applied to detect trends and the magnitude of change over the time period of 102 years (1901-2002). Mann Whitney Pettit's method and Cumulative deviations test were applied for detection of shift point in the series. The results obtained year 1951 to be the most probable shift point in annual rainfall. The trend analysis along with the percent change for the data series before (1901-1951) and after the shift point (1952-2002) was also done. A significant downward rainfall trend was found in annual, monsoon and winter rainfall over the period of 102 years. The maximum decrease was found for the Godda (19.77\%) and minimum at Purbi Singhbum station (1.95\%). Trend analysis before shift point, i.e., during 1901-1951 showed an upward trend in annual rainfall and after shift point (1952-2002) a downward trend. The trend analysis for entire Jharkhand demonstrated a significant downward trend in annual and monsoon rainfall with a decrease of $14.11 \%$ and $15.65 \%$ respectively. A downward trend in seasonal rainfall will have a more pronounced effect on agricultural activities in the area as it may affect the growth phase of the kharif crops (May-October) in the region.
\end{abstract}

Keywords: Mann Kendall test; rainfall trends; Jharkhand; climate change

\section{Introduction}

The study of regional/local climate change has been a subject of extensive research for few decades. One of the major reasons for the increased emphasis on these studies could be due to the changing pattern of rainfall as observed in several parts of the world [1-3]. Dore [4] observed that rainfall rich areas have become more rich while, dry and arid areas have experienced increased dryness for the past few years. On a global scale, the average precipitation is expected to increase, but on regional scale it is predicted to show the pattern of increase and vice versa [5]. However, since the end of the 19 th century, the global terrestrial precipitation has augmented by about $2 \%$ [6,7]. The Phenomenon of El Niño Southern Oscillation (ENSO) is the most important driver of global climate variability, which modifies rainfall distribution temporarily. Global scale variability in rainfall tends to be substantially higher in ENSO (El Niño) affected areas [8].

Atmospheric circulation patterns have a direct impact on monsoon and its weakening leads to changes in precipitation. In India, $40 \%$ of the population is dependent on monsoon for agriculture. About $54 \%$ (75.5 million ha) of the net sown area is still dependent on monsoon rainfall [9]. The anomaly of sea surface temperature over the Indian Ocean influences the variability in the monsoon rainfall [10]. In the context of climate change, it is relevant to find out how the characteristics of Indian summer 
monsoon are changing. Hydrologists have put the emphasis on trend analysis of Indian summer monsoon rainfall [11].

Fluctuations in rainfall events are a result of the changes of the hydrological cycle due to global warming. An understanding of these changing pattern of rainfall are required for the sustainable agriculture and water resource management. Rotstayn and Lohmann [12] observed in their modelling studies, a shift in tropical rainfall trends over land (tropics) for the period 1900-1998 and found it as a result of indirect effects of sulphate aerosols. Krishnakumar et al. [13] found a significant decline in rainfall during the southwest monsoon and an increase during the post-monsoon season over Kerala. Subash et al. [14] investigated rainfall trends at four stations namely Madhepura, Sabour, Samastipur and Patna and found an upward annual rainfall trend over all the stations except Samastipur. Patra et al. [15] reported long term (1871-2006) insignificant downward trend of annual as well as monsoon rainfall, whereas an upward trend in post-monsoon season over Orissa. Basistha et al. [16] observed a downward rainfall trend as a sudden shift rather than gradual trend over Indian Himalayas. Kumar and Jain [17] also found downward trend in the annual rainfall as well as rainy days in 15 out of 22 basins in India. Studies over states of Chhattisgarh [18] and Madhya Pradesh also reported downward rainfall trends [19].

For the management and planning at regional or local scale it has been found that continental or global scale studies of climate variables are not very much useful $[20,21]$. Therefore, the regional and local level climatic variables studies are required for the same. The rainfall trend analysis is important to assess the impact of climate change; therefore, in this study, an effort has been made to determine the rainfall climatology at the district level over Jharkhand. The foremost aim of the present study is to analyze the changes in yearly and seasonal rainfall over each station over a period of 102 years (1901-2002).

\section{Materials and Methodology}

\subsection{Description of Study Area}

Jharkhand is a tribal dominant state and is often called as the "Land of Forest", extending over a geographical area of $74,677 \mathrm{~km}^{2}$. The state is bordered by five other states- Bihar in the north, Uttar Pradesh, and Chhattisgarh in the west, West Bengal in the east and Orissa in the south. It lies between $23^{\circ} 37^{\prime} 3^{\prime \prime} \mathrm{N}$ and $24^{\circ} 4^{\prime} \mathrm{N}$ latitude and between $86^{\circ} 6^{\prime} 30^{\prime \prime} \mathrm{E}$ and $86^{\circ} 50^{\prime} \mathrm{E}$ longitude with an altitude ranging from 3 to $1359 \mathrm{~m}$ (Figure 1). The state has a cultivation area of about 1.8 million ha comprising $22 \%$ of the geographical area. There are three agro climatic zones in Jharkhand i.e., central, north eastern and south eastern plateau sub zones. It is rich in mineral deposits like iron ore, coal, mica, copper, bauxite and uranium. The state has high potential for higher production of horticulture and forest products. Here the soil is newly formed and has good capacity of humus formation. Kharif (June-September) is the main cropping season in the state that is heavily dependent on the monsoon. In Rabi season (October-November) cropping is not possible because of undependable rains during this season. In non-monsoon season, irrigation sources is very limited and mostly unavailable, while during monsoon season cultivation is possible due to the availability of rainfall and during non-monsoon season farmers cannot depend on rainfall due to its less occurrence frequency (undependable rainfall). The yield of Kharif crops, chiefly paddy (dominant crop) has been adversely affected due to decline in rainfall in recent years [22]. Hydro power production has been also declined in recent years due to the unavailability of adequate amount of water in river dams that requires heavy rainfall to feed the reservoir for its operation. 


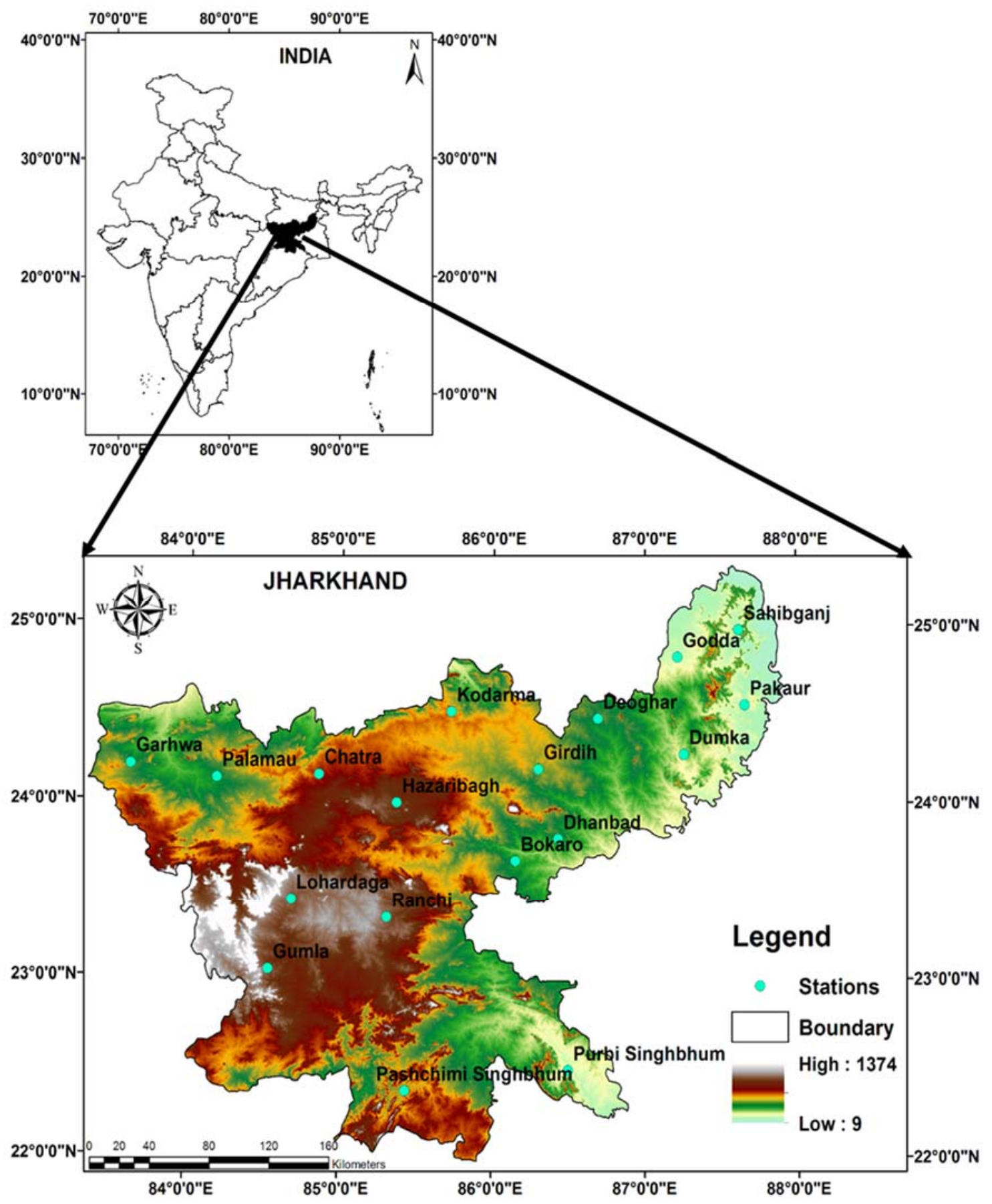

Figure 1. Jharkhand study area showing rain gauge stations along with elevation (in meters).

\subsection{Data Collection}

The monthly Rainfall data was downloaded from the website of India water portal for Jharkhand state for the period 1901-2002 [23]. India Metrological Department (IMD) is a centrally funded agency that is responsible for the collection of meteorological observation data, weather prediction and seismology. IMD has defined four seasons, namely winter (January-February), pre-monsoon (March-May), monsoon (June-September) and post-monsoon (October-December) so using monthly rainfall data, seasonal and annual rainfall series were prepared. For the homogeneity analysis, the cumulative deviations test was applied at $1 \%$ significance level and the results showed that, the series to be reliable and homogeneous. It is also used for shift point detection in the data series. 


\subsection{Methodology}

As a first step of analysis, basic statistical parameters like mean, standard deviation (SD), skewness, kurtosis and coefficient of variation were estimated from the data for each station. Initially the Autocorrelation test was applied to check serial dependence in the dataset. Strong autocorrelations affect the significance assessment of trend estimates by inflating the distribution of the test statistics. These much larger critical values need to be employed as significance thresholds than in case of uncorrelated data. Apart from this, Loess regression curve was used to plot and check general patterns in data over the period of 1901-2002 for annual and seasonal series.

In general, both parametric and non-parametric tests are used for trend analysis but non parametric test is preferred as it does not require data to be normally distributed. Hydrometeorological data are generally non normal, hence non-parametric statistical tools like Mann-Kendall test and Sen's slope method were used to detect the direction and magnitude of a trend respectively in the present study. For the shift point detection the non-parametric tests like Mann-Whitney-Pettitt (PWM) test [24] and Cumulative Deviations (CD) [25] were also applied. Apart from this, for spatial and temporal trend analysis the linear regression slopes were interpolated using kriging in the present study. The detailed methodology is given below.

\subsubsection{Autocorrelation}

Lag-1 autocorrelation is used to check serial dependence between the data [26]. The lag-1 autocorrelation coefficient is the simple correlation coefficient of the first observations $N-1, X_{t}$, $t=1,2,3, \ldots, N-1$ and the next observations, $X_{t+1}, t=2,3, \ldots, N$. The correlation between $X_{t}$ and $X_{t+1}$ is given by

$$
r_{1}=\frac{\sum_{t=1}^{N-1}\left(X_{t}-X\right)\left(X_{t+1}-\bar{X}\right)}{\sum_{i=1}^{N}\left(X_{t}-\bar{X}\right)^{2}}
$$

where $\bar{X}=\sum_{t=1}^{N} X_{t}$ is the overall mean.

The lag-1 autocorrelation coefficient $r_{1}$ is tested for its significance. The probability limits on the correlogram of an independent series of the two tailed test is given below [18].

$$
r_{1}(95 \%)=\frac{-1 \pm 1.96 \sqrt{N-k-1}}{N-k}
$$

where $N$ is the sample size and $k$ is the lag.

If the value of $r_{1}$ lie outside the confidence interval given above, the data are assumed to be serially correlated otherwise the sample data are considered to be serially independent.

\subsubsection{Mann-Kendall trend test}

Mann-Kendall test is a non-parametric test. It is frequently used for the detection of significant trend in hydrologic data series [15]. The MK test, $S$ statistics for a series $X_{1}, X_{2}, \ldots, X_{n}$ can be given by:

$$
S=\sum_{i=1}^{n-1} \sum_{j=i+1}^{n} \operatorname{sgn}\left(X_{j}-X_{i}\right)
$$

where $X_{i}$ is ranked from $i=1,2, \ldots, n-1$ and $X_{j}$ is ranked from $j=i+1$ and $n$ is the length of the data set.

$$
\operatorname{sgn}(\vartheta)=\left\{\begin{array}{l}
1 \ldots \text { if } \vartheta>0 \\
0 \ldots \text { if } \vartheta=0 \\
-1 \ldots \text { if } \vartheta<0
\end{array}\right.
$$


Positive (negative) signs of the test statistics $S$ indicate upward (downward) trend in the data. For the sample size $n \geq 8$, variance of the Mann-Kendall statistics is given by:

$$
\operatorname{Var}(S)=\frac{\left[n(n-1)(2 n+1)-\sum_{t} t(t-1)(2 t+5)\right]}{18}
$$

where $t_{i}$ is the number of ties present upto sample $i$.

The standardized MK test statistics $\left(Z_{m k}\right)$ can be estimated by the following given formula:

$$
Z_{m k}=\left\{\begin{array}{c}
\frac{S-1}{\sqrt{V(S)}} \text { if } S>0 \\
0 \text { if } S=0 \\
\frac{S+1}{\sqrt{V(S)}} \text { if } S<0
\end{array}\right.
$$

The $Z_{m k}$ follows a standard normal distribution and if its value is positive, it signifies an upward trend and if its value is negative it signifies a downward trend. If the value of $Z_{m k}$ is greater than $Z_{\alpha / 2}$ then it is considered as significant trend (where $\alpha$ is significance level) and the null hypothesis is rejected.

\subsubsection{Sen's Method}

This is a nonparametric method [27] that assumes a linear trend in the time series data and an uncorrelated data. This method is robust to missing data and outliers in the data series. It quantifies the median (50th percentile) concentration changes linearly with time and is used to determine the magnitude of the trend line. The slope of trend line in the sample of $N$ pairs of data can be estimated by:

$$
Q=\frac{X_{j}-X_{i}}{i-i^{\prime}}
$$

where $X_{j}$ and $X_{i}^{\prime}$ are the data values at times $i$ and $i^{\prime}\left(i>i^{\prime}\right)$, respectively.

The median of these $N$ values of $Q$ is Sen's estimator of slope which is calculated as

$$
\begin{gathered}
\beta=Q\left(\frac{N+1}{2}\right) \text { if } N \text { is odd } \\
\beta=(Q(N / 2)+Q(N+2) / 2)) / 2 \text { if } N \text { is even }
\end{gathered}
$$

A positive value of $\beta$ indicates an upward (increasing) trend and a negative value indicates a downward (decreasing) trend in the time series.

The $\beta$ sign reflects data trend direction, while its value indicates the steepness of the trend. To determine whether the median slope is statistically different than zero, one should obtain the confidence interval of $\beta$ at specific probability. The confidence interval about the median slope can be computed as follows.

$$
C_{\alpha}=Z_{1-\alpha / 2} \times \sqrt{\operatorname{Var}(S)}
$$

where Variance $(S)$ is

$$
\operatorname{Var}(S)=\frac{1}{18}\left[n(n-1)(2 n+5)-\sum_{p-1}^{q} t p(t p-1)(2 t p+5)\right]
$$

$Z_{1-\alpha / 2}$ is obtained from the standard normal distribution table.

The lower and upper limits of confidence interval, $M_{1}$ and $M_{2}$ are computed as

$$
M_{1}=\frac{N-C_{\alpha}}{2}
$$




$$
M_{2}=\frac{N+C_{\alpha}}{2}
$$

\subsubsection{Mann-Whitney-Pettit Test}

Let $t$ be the most likely change point year of a time series $\left(X_{1}, X_{2}, \ldots, X_{n}\right)$ with a length of $n$. Two partial time series, $\left\{X_{1}, X_{2}, \ldots, X_{t}\right\}$ and $\left\{X_{t+1}, X_{t+2}, \ldots, X_{n}\right\}$, can then be derived by dividing the time series at time $t$. The $U_{t}$ statistics for the series can be given by

$$
U_{t T}=\sum_{i=1}^{t} \sum_{j=t+1}^{n} \operatorname{sgn}\left(X_{i}-X_{j}\right)
$$

A continuous increase in the value of $U_{t T}$ when plotted with $\mathrm{t}$ will indicate absence of change point but when the value of $\left|U_{t T}\right|$ increases initially and then decreases after a point, it will indicate presence of change point. The point where maximum value of $U_{t}$ is obtained is considered as the most probable change point.

$$
K_{T}=\max _{1 \leq t \leq T}\left|U_{t T}\right|
$$

\subsubsection{Cumulative Deviations Test}

Here the null hypothesis says that the time series variable is independently and identically distributed and the alternate hypothesis says, that there is a shift in the mean value after a certain time.

The test can still be applied, however, when there are slight departures from normality. The departure from homogeneity is tested using the statistics, which is defined as

$$
Q=\max _{1 \leq k \leq n}\left|S_{k}^{*}\right|
$$

In which the rescaled adjusted partial sums are obtained by dividing the $S_{k}$ by the sample standard deviation $\left(D_{X}\right)$.

$$
S_{k}^{*}=\frac{S_{k}}{D_{X}}
$$

where $S_{k}$ can be computed by

$$
S_{k}=\sum_{i=1}^{k}\left(X_{i}-\bar{X}\right)
$$

This test is based on the adjusted partial sums or cumulative deviations from the mean of the time series data. If the magnitude of $Q / \sqrt{ } \mathrm{n}$ exceeds the value at the considered critical level then the time series is heterogeneous (Yu et al., 2006). Critical values of $\mathrm{Q} / \sqrt{ } \mathrm{n}$ for the $99 \%$ confidence limits are used in this study [25].

\section{Results}

\subsection{Preliminary Investigation}

Monthly and seasonal characteristics of rainfall over each station were calculated for the period 1901-2002 (Table 1). Annual precipitation varied between $1211 \mathrm{~mm}$ in the northwestern part (Chatra station) and $1383 \mathrm{~mm}$ in eastern part (Pakaur station) of Jharkhand. The standard deviation varied between $184 \mathrm{~mm}$ and $256 \mathrm{~mm}$ (Figure 2a). The skewness, which is a measure of the asymmetry in frequency distribution around the mean, varied between -0.04 and 0.81 indicating that annual rainfall during the period is asymmetric and it lies to the right of the mean over all the stations. Kurtosis varied from -0.34 to 1.73 which describes the peakedness of a symmetrical frequency distribution. 
Table 1. Statistical Analysis of rainfall ( $\mathrm{mm})$ over the study area.

\begin{tabular}{cccccc}
\hline Stations & Mean $(\mathbf{m m})$ & SD $(\mathbf{m m})$ & Skewness & Kurtosis & CV (\%) \\
\hline Bokaro & 1358 & 230 & 0.41 & 1.26 & 17.0 \\
Chatra & 1211 & 257 & 0.11 & 0.15 & 21.2 \\
Deogarh & 1312 & 234 & 0.61 & 0.55 & 17.8 \\
Dhanbad & 1341 & 217 & 0.60 & 1.51 & 16.2 \\
Dumka & 1346 & 236 & 0.60 & 0.57 & 17.5 \\
Garhwa & 1222 & 247 & -0.04 & -0.29 & 20.2 \\
Giridih & 1300 & 232 & 0.48 & 0.84 & 17.9 \\
Godda & 1285 & 228 & 0.38 & -0.34 & 17.8 \\
Gumla & 1370 & 241 & 0.39 & 0.52 & 17.6 \\
Hazaribagh & 1305 & 242 & 0.29 & 0.72 & 18.5 \\
Kodarma & 1256 & 240 & 0.27 & 0.54 & 19.1 \\
Lohardaga & 1295 & 247 & 0.30 & 0.27 & 19.1 \\
Pakaur & 1383 & 246 & 0.41 & 0.05 & 17.8 \\
Palamau & 1225 & 257 & 0.05 & -0.12 & 21.0 \\
Paschimi Singhbhum & 1280 & 187 & 0.81 & 1.73 & 14.6 \\
Purbi Singhbhum & 1310 & 184 & 0.65 & 1.40 & 14.1 \\
Ranchi & 1300 & 215 & 0.49 & 0.93 & 16.6 \\
Sahibganj & 1348 & 227 & 0.31 & -0.24 & 16.8 \\
\hline
\end{tabular}
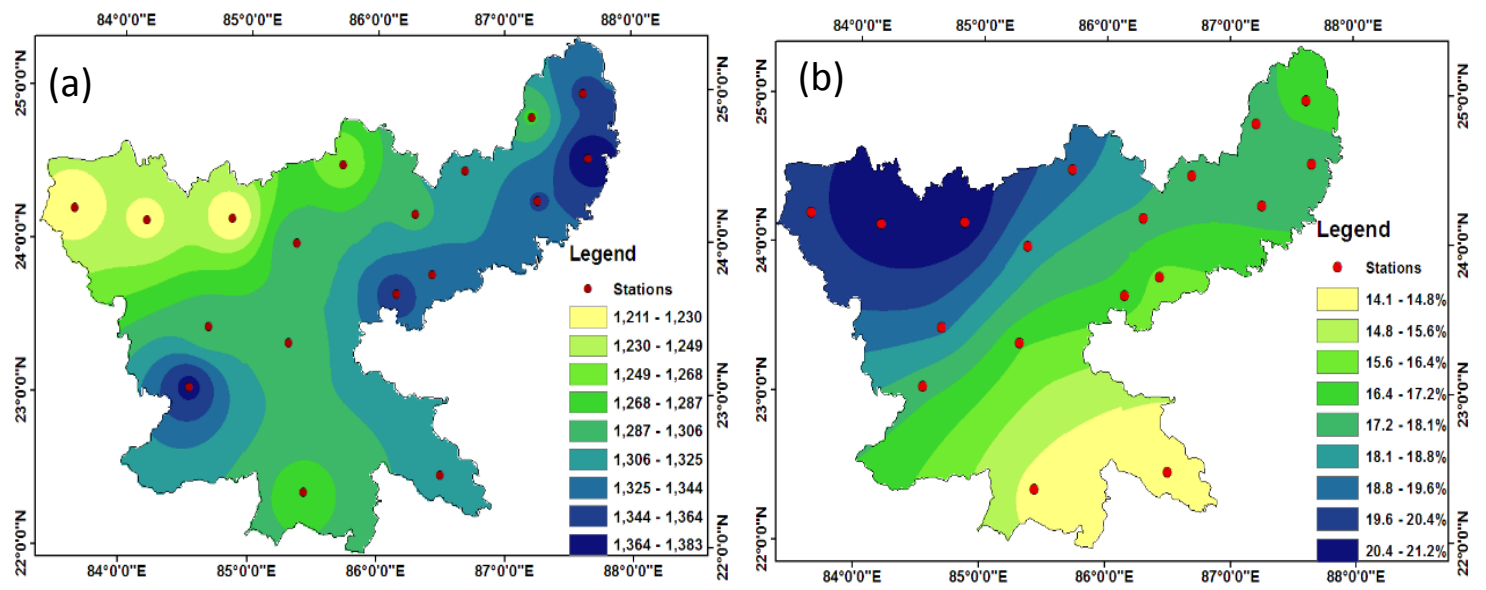

Figure 2. The spatial distribution of (a) rainfall and (b) Coefficient of variation in annual rainfall over the period of 1901-2002.

For the computation of rainfall variability, the formula of coefficient of variation was used. Coefficient of variation $(\mathrm{CV})$ is a statistical measure of the dispersion of data points in a data series around the mean. The value of Coefficient of variation ranged between 14.1\% (Purbi Singhbhum) and $21.2 \%$ (Chatra) with an average coefficient of variation $17.8 \%$ for the entire state (Figure $2 b$ ).

\subsection{General Pattern Analysis in Precipitation}

For the assessment of the long term pattern of precipitation, standardized series were prepared using 102 year period data for both annual and seasonal time series. The average of all the stations data was calculated for annual and seasonal scale and further standardization was performed using these averaged series. The moving average is not resistant (robust) to local fluctuations therefore, to reduce the local fluctuations, the standardized data series were fitted with LOESS [28-30] regression curves to identify patterns over time. The Loess curve of annual precipitation (Figure 3a) displayed a gradual rise in precipitation up to year 1941. It reached the highest value in 1941. From 1941 onwards, it showed a downward trend up to 2002 and reached the lowest value in 2002. This graph indicated a decrease in rainfall in the 2 nd half of the century. Figure $3 b$ presents the Loess regression curves 
for seasonal rainfall series. From Figure $3 b$ it can be seen that monsoon rainfall series has followed a similar trend to annual rainfall series. The winter rainfall displayed a minor rise up to year 1939. From 1940 onwards, it indicated a decreasing trend up to 1963 and then slightly increased. The post-monsoon rainfall showed very slight increase up to 1962. From 1963 onwards, it decreased up to 1978 and then slightly increased. Pre-monsoon rainfall showed a decline in rainfall from 1924 onward up to 1960 and afterwards an increase was observed.
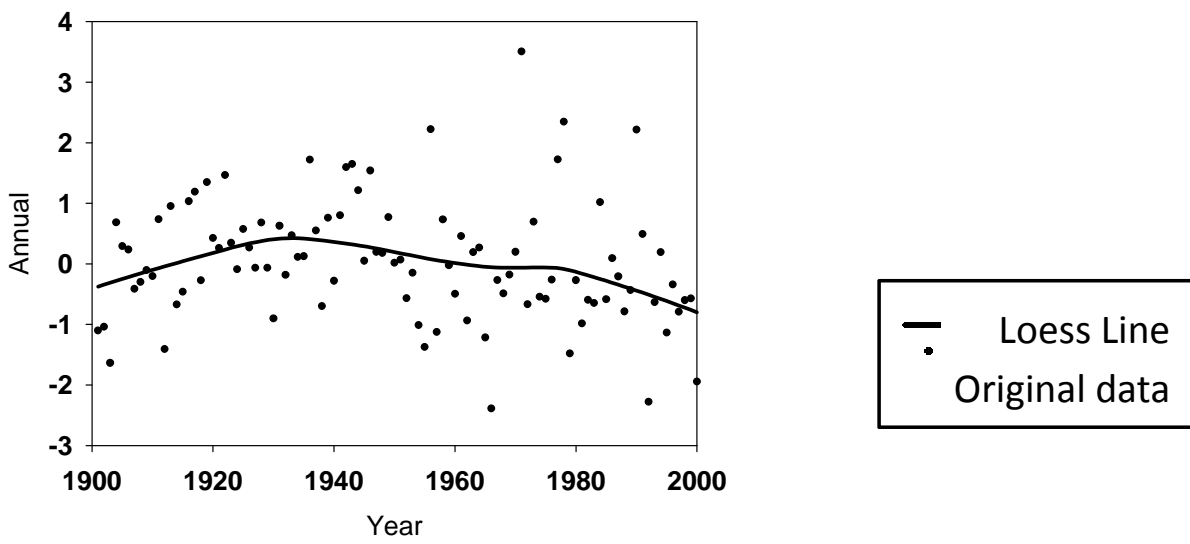

(a)
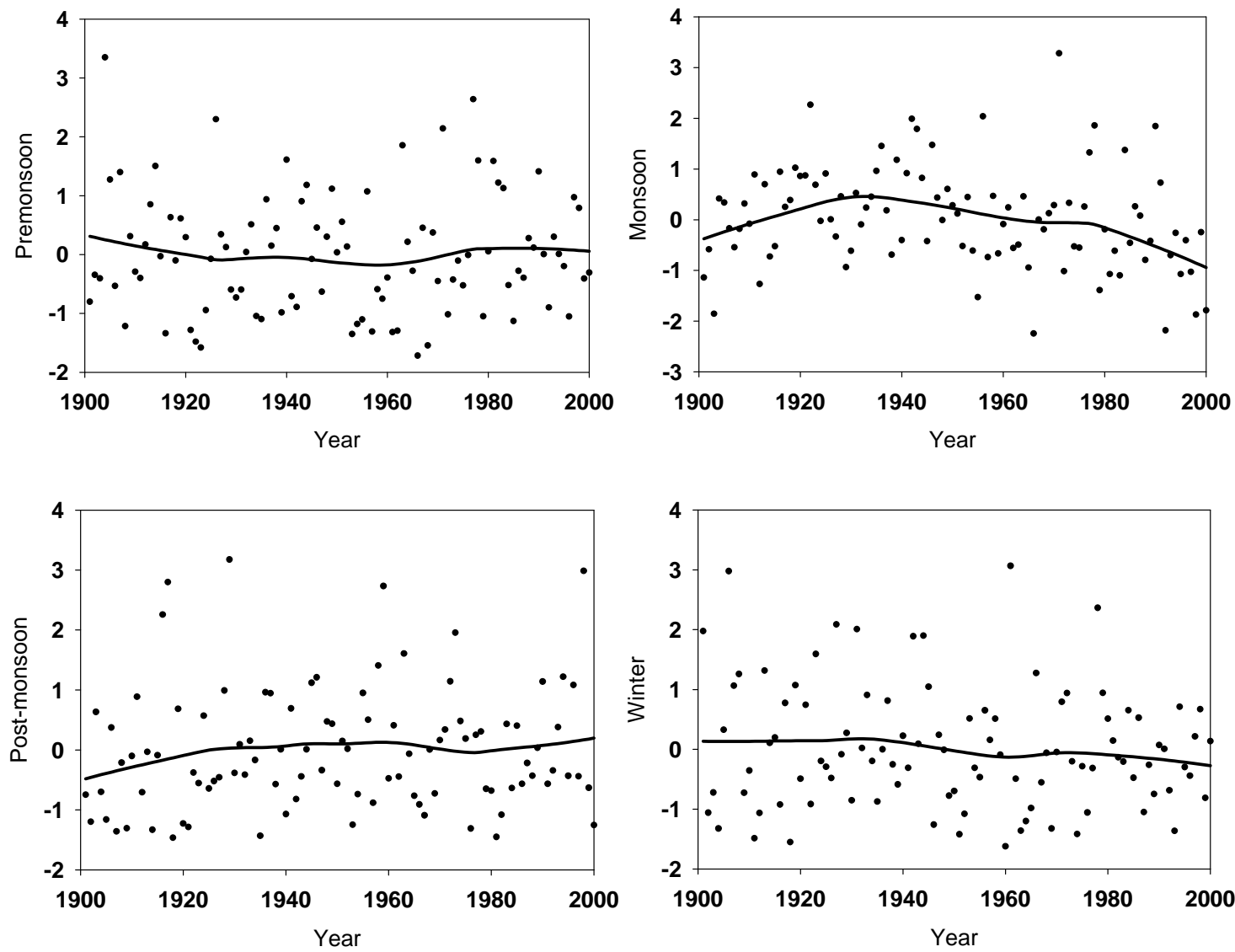

(b)

Figure 3. Loess regression curve of (a) Annual and (b) Seasonal rainfall. 


\subsection{Rainfall Trend and Percent Change Analysis}

Lag-1 autocorrelation was used to detect the serial correlation in the dataset. None of the data series was found serially correlated so, the Mann-Kendall (MK) test was applied to compute the trend in the data. The results of MK test and Sen's slope are demonstrated in Figure 4 and Table 2 respectively. The percent change in annual and seasonal rainfall is shown in Figure 4. Significant downward trends in annual rainfall were observed over all the stations except Paschimi Singhbhum and Purbi Singhbhum which showed an insignificant downward trend. The slope of the downward trends in annual precipitation ranged between 0.25 (at Purbi Singhbhum station of Northeastern zone) to $2.49 \mathrm{~mm}$ per year (at Godda station of southeastern zone).
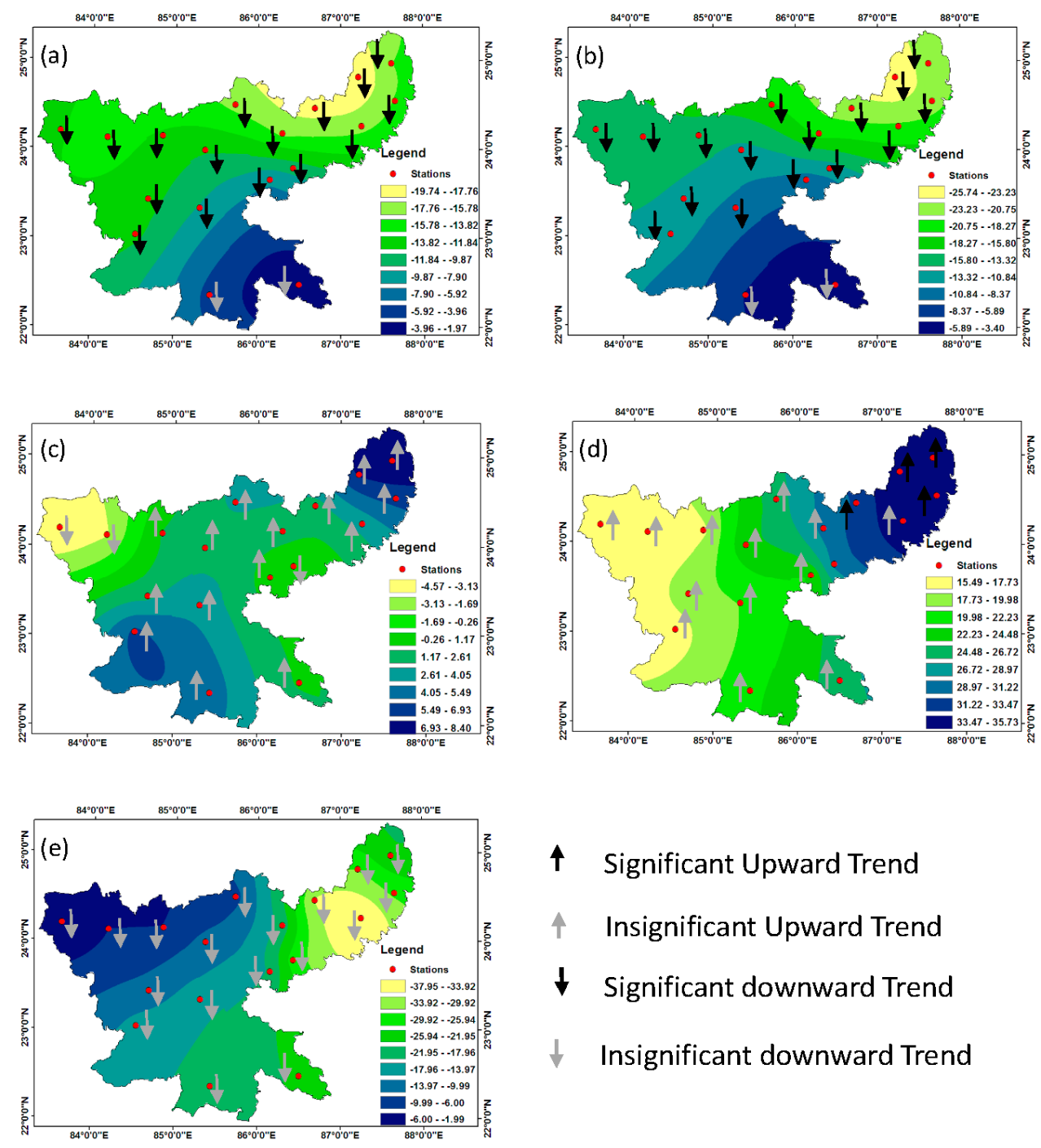

\section{$\uparrow \quad$ Significant Upward Trend}

4 Insignificant Upward Trend

$\downarrow$ Significant downward Trend

$\Downarrow$ Insignificant downward Trend

Figure 4. Spatial distribution of percent change over mean and trend analysis (Mann Kendall statistics) for period 1901-2002 of (a) Annual; (b) Monsoon; (c) Pre-monsoon; (d) Post-monsoon and (e) Winter season.

No significant results were found during Pre-monsoon rainfall. An insignificant upward trend was observed over all the stations except three stations namely, Palamau, Dhanbad and Garhwa that showed an insignificant downward trend. While monsoon rainfall showed the significant downward trends over all the stations except Purbi Singhbhum and Paschimi Singhum. The post monsoon rainfall showed significant upward rainfall trends at Dumka, Sahibganj, Deogarh, Pakaur and Godda. 
During winter season, downward trends were prevalent in all the stations, but the significant trends were shown by Dumka and Deogarh only.

Table 2. Sen's slope ( $\beta$ ) value of Annual and Seasonal rainfall (1901-2002).

\begin{tabular}{cccccc}
\hline \multirow{2}{*}{ Time (1901-2002) Series } & Annual & Monsoon & Premonsoon & Postmonsoon & Winter \\
\cline { 2 - 6 } & $\boldsymbol{\beta}$ & $\boldsymbol{\beta}$ & $\boldsymbol{\beta}$ & $\boldsymbol{\beta}$ & $\boldsymbol{\beta}$ \\
\hline Bokaro & -1.11 & -1.08 & 0.00 & 0.20 & -0.10 \\
Chatra & -1.62 & -1.52 & 0.01 & 0.13 & -0.03 \\
Deogarh & -2.40 & -2.38 & 0.01 & 0.29 & -0.14 \\
Dhanbad & -1.41 & -1.29 & -0.01 & 0.27 & -0.14 \\
Dumka & -2.17 & -2.20 & 0.03 & 0.35 & -0.15 \\
Garhwa & -1.64 & -1.52 & -0.02 & 0.11 & -0.01 \\
Giridih & -2.09 & -2.05 & 0.02 & 0.26 & -0.09 \\
Godda & -2.49 & -2.68 & 0.07 & 0.34 & -0.10 \\
Gumla & -1.66 & -1.44 & 0.04 & 0.11 & -0.07 \\
Hazaribagh & -1.54 & -1.34 & 0.02 & 0.20 & -0.06 \\
Kodarma & -2.01 & -1.9 & 0.02 & 0.21 & -0.04 \\
Lohardaga & -1.60 & -1.4 & 0.01 & 0.14 & -0.06 \\
Pakaur & -2.11 & -2.4 & 0.07 & 0.38 & -0.1 \\
Palamau & -1.73 & -1.6 & 0 & 0.11 & -0.03 \\
Pashchimi Singhbhum & -0.66 & -0.6 & 0.05 & 0.18 & -0.1 \\
Purbi Singhbum & -0.25 & -0.3 & 0.01 & 0.26 & -0.11 \\
Ranchi & -1.24 & -1.1 & 0.03 & 0.16 & -0.09 \\
Sahibganj & -2.10 & -2.3 & 0.1 & 0.36 & -0.07 \\
\hline
\end{tabular}

The downward trend of rainfall during monsoon (June-September) would adversely affect the yield of rice crops. The decrease in rainfall in almost all the seasons may drastically affect the agricultural activities and groundwater, surface water resources in the area. The Percent change more than $10 \%$ were shown by 14 annual series and 15 monsoon series. It was found least during pre-monsoon season and the maximum in winter season.

\subsection{Shift Point Analysis}

For shift point detection in annual series the Mann-Whitney-Pettitt (MWP) and the cumulative deviation test were used. The results were shown in Table 3. The most probable shift point was year 1951 as depicted from both the MWP and Cumulative deviation test.

Table 3. Results of MWP test and Cumulative deviation test.

\begin{tabular}{ccccc}
\hline \multirow{2}{*}{ Stations Name } & \multicolumn{2}{c}{ MWP Test } & \multicolumn{2}{c}{ Cumulative Deviation Test } \\
\cline { 2 - 5 } & Shift Point & $p$ Value & Shift Point & $\mathbf{Q} \sqrt{ } \mathbf{n}$ \\
\hline Bokaro & 1951 & 0.033 & 1951 & 0.99 \\
Chatra & 1951 & 0.02 & 1951 & 1.18 \\
Deogarh & 1954 & 0.001 & 1957 & 1.46 \\
Dhanbad & 1952 & 0.015 & 1951 & 1.07 \\
Dumka & 1957 & 0.002 & 1957 & 1.40 \\
Garhwa & 1951 & 0.025 & 1951 & 1.31 \\
Giridih & 1952 & 0.002 & 1979 & 1.40 \\
Godda & 1960 & 0 & 1960 & 1.77 \\
Gumla & 1950 & 0.019 & 1950 & 1.16 \\
Hazaribagh & 1951 & 0.024 & 1979 & 1.11 \\
Kodarma & 1951 & 0.006 & 1979 & 1.37 \\
Lohardaga & 1950 & 0.02 & 1950 & 1.15 \\
Pakaur & 1960 & 0.001 & 1957 & 1.46 \\
Sahibganj & 1960 & 0 & 1957 & 1.60 \\
\hline
\end{tabular}


Table 3. Cont.

\begin{tabular}{ccccc}
\hline \multirow{2}{*}{ Stations Name } & \multicolumn{2}{c}{ MWP Test } & \multicolumn{2}{c}{ Cumulative Deviation Test } \\
\cline { 2 - 5 } & Shift Point & $p$ Value & Shift Point & $\mathbf{Q} \sqrt{ } \mathbf{n}$ \\
\hline Palamau & 1951 & 0.02 & 1951 & 1.27 \\
Paschimi & 1950 & 0.051 & 1950 & 0.83 \\
Singhbhum & & 0.307 & 1950 & 0.55 \\
Purbi Singhbhum & 1950 & 0.029 & 1950 & 1.02 \\
Ranchi & 1950 & 0 & 1957 & 1.60 \\
Sahibganj & 1960 & & &
\end{tabular}

\subsection{Trend Analysis of Two Time Series (Annual) i.e., 1901-1951 and 1952-2002}

The results of trend analysis for both partial time series were shown in Figures 5 and 6 for the periods 1901-1951 and 1952-2002 respectively. The trend analysis of two time series, i.e., before (1901-1951) and after the shift point (1952-2002) showed opposite results. Annually significant upward rainfall trends were found in all the stations except Purbi Singhbhum during the period 1901-1951. While, for the period 1901-2002 the downward trend was found in all the stations, but significant trends were shown by Godda and Deogarh. The results for monsoon season showed significant downward trends for 9 stations namely, Deogarh, Dhanbad, Garhwa, Giridih, Godda, Kodarma, Pakaur, Palamau and Sahibganj. Overall, it can be concluded that a decrease in rainfall has occurred over the entire time period. Percent change was computed for the period 1901-1951 and 1952-2002 and presented in Tables 4 and 5 respectively. Maximum increasing \% change in annual rainfall was found at Chatra (20.55\% during 1901-1951) and maximum decreasing \% change in annual rainfall was found at Palamau (-18.15\% during 1952-2002).
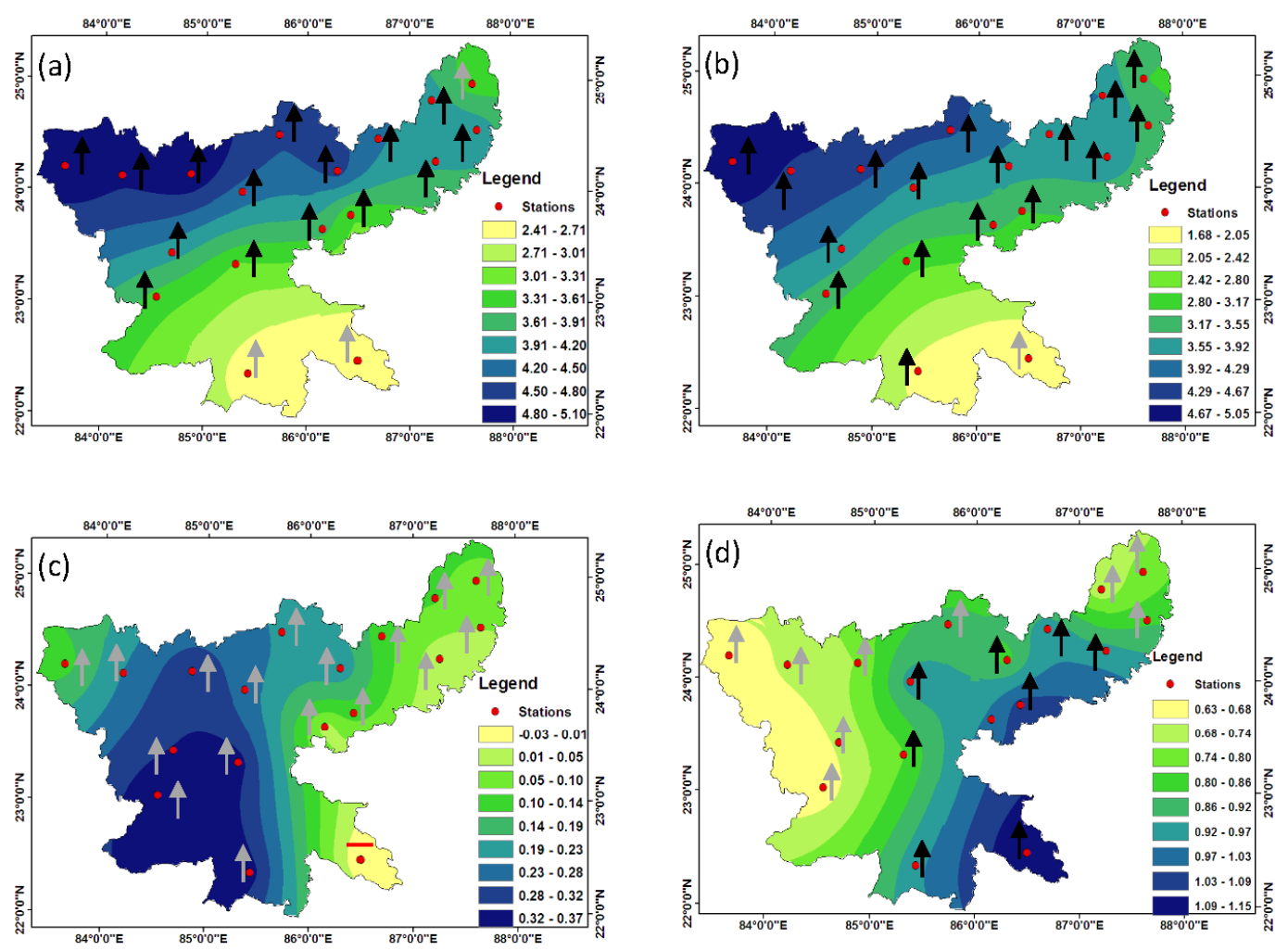

Figure 5. Cont. 


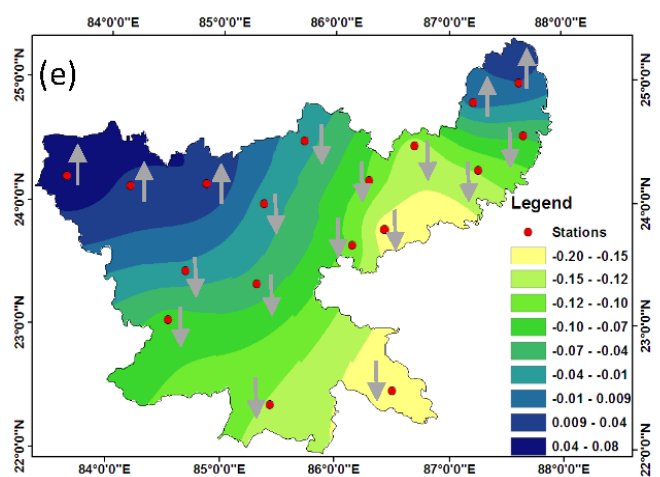

$\uparrow \quad$ Significant Upward Trend

$\uparrow$ Insignificant Upward Trend

$\downarrow$ Significant downward Trend

$\downarrow$ Insignificant downward Trend

- No Trend

Figure 5. Spatial distribution of Sen's slope value and trend direction (Mann Kendall statistics) from 1901-1951of (a) Annual; (b) Monsoon; (c) Pre-monsoon; (d) Post-monsoon and (e) Winter season.
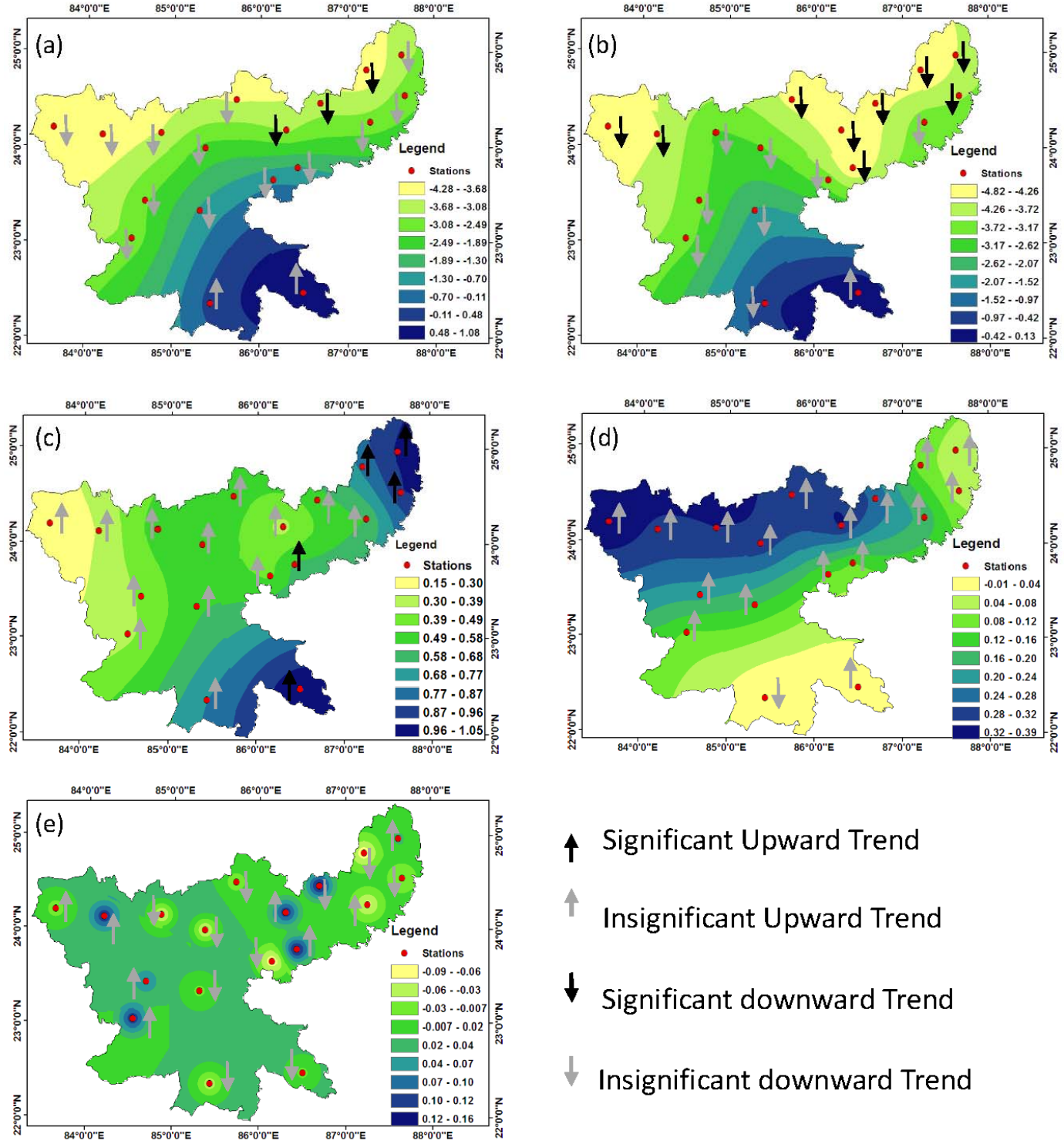

\section{$\uparrow$ Significant Upward Trend \\ $\uparrow$ Insignificant Upward Trend \\ $\downarrow$ Significant downward Trend \\ $\downarrow$ Insignificant downward Trend}

Figure 6. Spatial distribution of Sen's slope value and trend direction (Mann Kendall statistics) from 1952-2002 of (a) Annual; (b) Monsoon; (c) Pre-monsoon; (d) Post-monsoon and (e) Winter season. 
Table 4. Percent change of Annual and Seasonal rainfall (1901-1951).

\begin{tabular}{cccccc}
\hline 1901-1951 & Annual & Pre-Monsoon & Monsoon & Post-Monsoon & Winter \\
\hline Stations & \% Change & \% Change & \% Change & \% Change & \% Change \\
\hline Bokaro & 13.65 & 2.09 & 14.48 & 56.53 & -5.14 \\
Chatra & 20.55 & 24.99 & 21.14 & 49.71 & 3.31 \\
Deogarh & 15.76 & 7.15 & 16.80 & 55.67 & -9.86 \\
Dhanbad & 12.28 & 6.49 & 14.26 & 60.75 & -11.46 \\
Dumka & 14.34 & 1.43 & 16.66 & 51.11 & -7.07 \\
Garhwa & 20.28 & 15.56 & 23.12 & 44.29 & 5.62 \\
Giridih & 17.44 & 14.40 & 16.75 & 50.10 & -5.37 \\
Godda & 15.46 & 6.08 & 17.60 & 39.98 & 1.14 \\
Gumla & 12.62 & 29.74 & 13.79 & 49.34 & -7.59 \\
Hazaribagh & 16.52 & 16.15 & 17.28 & 58.02 & -2.44 \\
Kodarma & 17.45 & 16.14 & 20.00 & 55.07 & -1.88 \\
Lohardaga & 15.28 & 25.61 & 16.80 & 48.88 & -1.40 \\
Pakaur & 14.49 & 2.50 & 14.63 & 42.87 & -4.04 \\
Palamau & 19.27 & 22.41 & 21.28 & 49.58 & 1.40 \\
Pashchimi Singhbhum & 10.02 & 17.01 & 9.30 & 59.74 & -8.09 \\
Purbi Singhbum & 9.26 & -1.05 & 8.31 & 59.35 & -9.81 \\
Ranchi & 12.52 & 20.96 & 13.42 & 51.29 & -3.21 \\
Sahibganj & 12.37 & 3.51 & 13.96 & 40.30 & 1.05 \\
\hline
\end{tabular}

Table 5. Percent change of Annual and Seasonal rainfall (1952-2002).

\begin{tabular}{cccccc}
\hline 1952-2002 & Annual & Pre-Monsoon & Monsoon & Post-Monsoon & Winter \\
\hline Stations & \% Change & \% Change & \% Change & \% Change & \% Change \\
\hline Bokaro & -3.22 & 16.86 & -16.27 & 5.44 & -8.82 \\
Chatra & -16.18 & 55.12 & -16.43 & 21.82 & -8.58 \\
Deogarh & -13.75 & 35.58 & -22.10 & 14.79 & 21.84 \\
Dhanbad & -4.77 & 42.65 & -23.28 & 4.24 & 17.29 \\
Dumka & -11.25 & 19.49 & -16.39 & 10.78 & -11.40 \\
Garhwa & -18.00 & 20.36 & -23.17 & 28.61 & -3.16 \\
Giridih & -13.26 & 9.93 & -22.73 & 21.51 & 16.41 \\
Godda & -17.98 & 45.31 & -24.88 & 3.89 & -14.90 \\
Gumla & -11.26 & 27.65 & -15.25 & 7.42 & 16.52 \\
Hazaribagh & -9.35 & 41.60 & -15.33 & 19.48 & -8.00 \\
Kodarma & -16.07 & 42.67 & -22.78 & 17.31 & -3.49 \\
Lohardaga & -10.56 & 33.40 & -16.05 & 15.82 & 8.23 \\
Pakaur & -10.63 & 47.21 & -18.46 & 1.28 & -6.46 \\
Palamau & -18.15 & 29.16 & -22.16 & 21.29 & 14.92 \\
Pashchimi Singhbhum & 0.41 & 41.20 & -2.91 & -0.58 & -6.13 \\
Purbi Singhbum & 4.26 & 45.22 & 0.66 & 0.95 & -2.18 \\
Ranchi & -4.98 & 38.34 & -9.81 & 10.43 & -1.96 \\
Sahibganj & -13.04 & 46.35 & -21.20 & 3.15 & 5.29 \\
\hline
\end{tabular}

Out of 18 stations, only two stations (Deogarh and Dumka) showed significant downward trends during winter rainfall (1952-2002). Before shift point (1901-1951), none of the station showed significant downward trends in winter rainfall.

3.6. Comparative Analysis of Mean Annual Precipitation between Two Time Period (1901-1951 and 1952-2002)

Percentage change in annual rainfall was computed by calculating percentage of second period average (1952-2002) from first period average (1901-1951) to demonstrate the decrease in rainfall over all the stations. Table 6 showed the decrease in rainfall which was found lowest in Ranchi (-2.59) and highest in Godda (-10.45). This shows a higher variation in change percentage in the state. 
Table 6. Percentage change in the mean of 1901-1951 over the mean of 1952-2002.

\begin{tabular}{cccc}
\hline Station Name & Change Percentage & Station Name & Change Percentage \\
\hline Bokaro & -6.15 & Hazaribagh & -7.44 \\
Chatra & -9.03 & Kodarma & -9.43 \\
Deogarh & -9.65 & Lohardaga & -7.93 \\
Dhanbad & -6.62 & Pakaur & -8.79 \\
Dumka & -8.93 & Palamau & -9.58 \\
Garhwa & -9.46 & Paschimi Singhbhum & -4.16 \\
Giridih & -9.11 & Purbi Singhbhum & -2.59 \\
Godda & -10.45 & Ranchi & -6.06 \\
Gumla & -7.33 & Sahibganj & -8.73 \\
\hline
\end{tabular}

\subsection{Spatial Analysis of Precipitation Series}

To analyze the spatial behavioral changes in rainfall, the linear regression slope of each station was interpolated using Kriging in ArcGIS environment for the whole study period (1901-2002) and after shift (1952-2002) which is shown in Figures 7-11. The interpolated linear slopes for the annual precipitation for the period 1901 to 2002 (Figure 7a) indicated a negative slope all over the entire study area while for period 1952-2002 (Figure 7b), it varied from positive to negative. Positive linear slopes were found in Northern and South Eastern region that showed a decrease in rainfall from north to south east direction. For the whole study period, the negative slope value (which decreased up to $-2.10 \mathrm{~mm}$ /year) was less in comparison to entire duration (up to $-4.33 \mathrm{~mm} /$ year) in annual rainfall. While the rise in magnitude of trend is found only after the shift point (up to $0.84 \mathrm{~mm} /$ year). During monsoon season (Figure 8a,b) decrease in rainfall magnitude varied from -0.23 to $-2.29 \mathrm{~mm} /$ year for the whole study period. The maximum negative slopes were shown by Deogarh, Godda, Dumka, Sahibganj, and Pakaur. The rainfall magnitude varied from -0.11 to $-4.75 \mathrm{~mm} /$ year after shift point. Maximum negative slopes were shown by Chatra, Palamau, Deogarh, Kodarma, Godda, Dumka, and Sahibganj. Decline in rainfall increased during the period 1952-2002 as compared to the period 1901-2002.
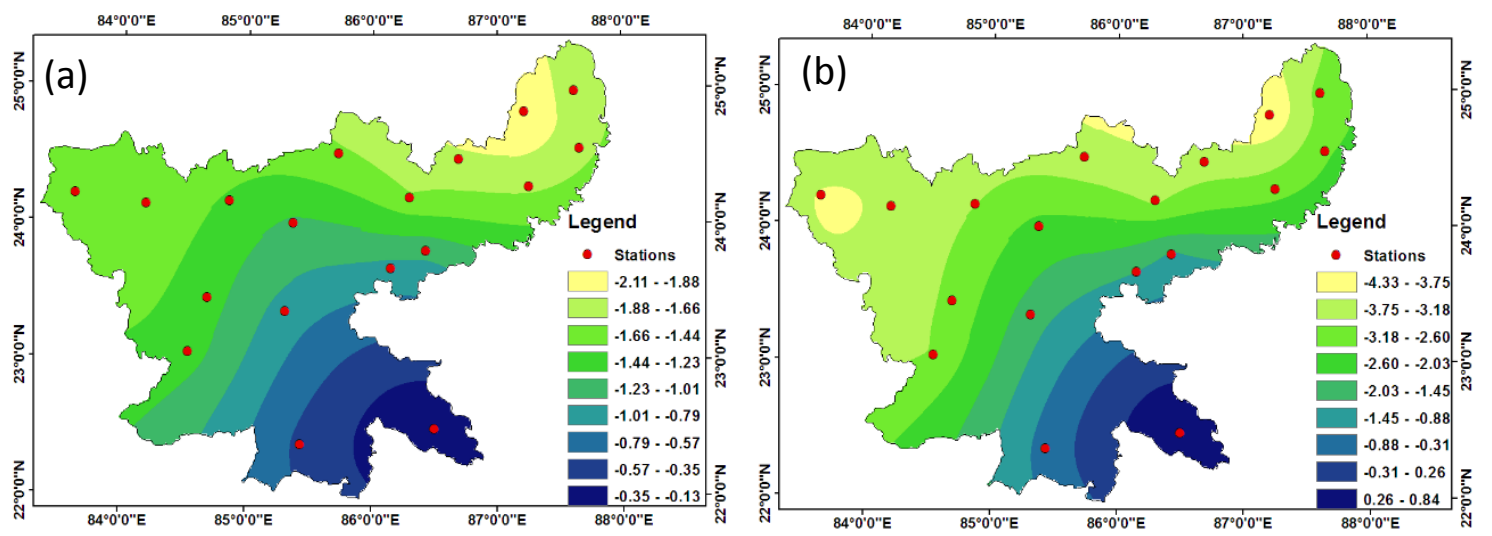

Figure 7. Spatial distribution of temporal change in Annual rainfall during 1901 to 2002 (a) and from 1952 to 2002 (b). 

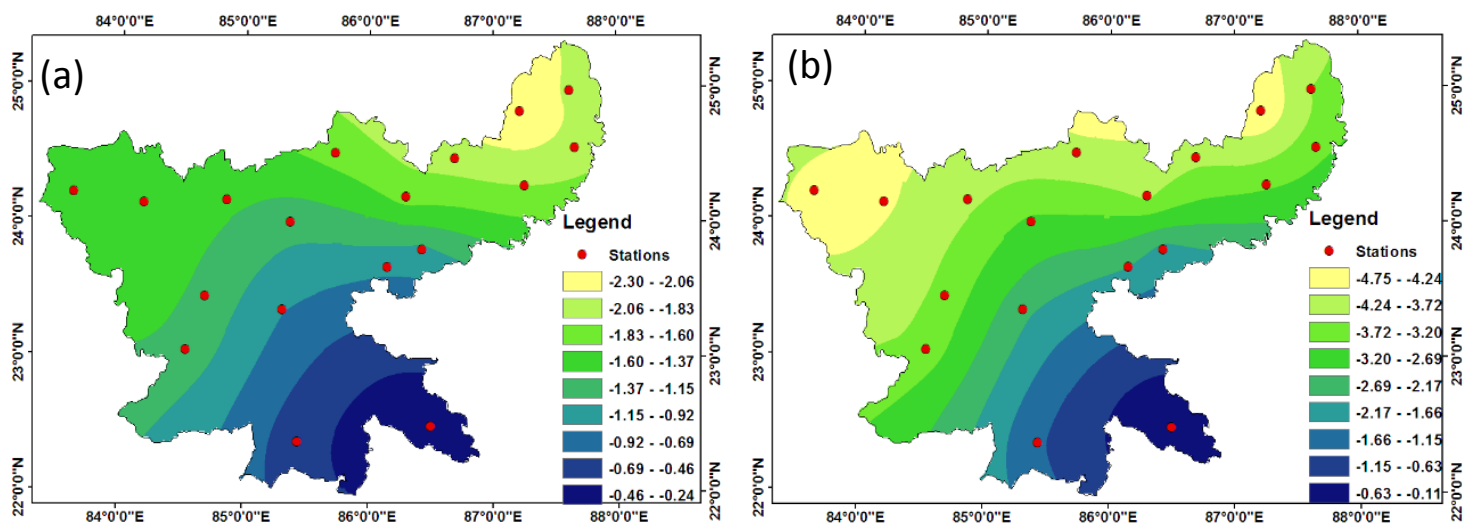

Figure 8. Spatial distribution of temporal change in Monsoon rainfall during 1901 to 2002 (a) and from 1952 to 2002 (b).

In the pre-monsoon season the rainfall magnitude varied between -0.0407 to $0.0823 \mathrm{~mm} /$ year during 1901-2002 (Figure 9a,b) and the negative slopes were prominent from western to the southern region. The stations that showed negative slopes were Garhwa, Palamau, Chatra Hazaribagh, Chatra, Kodarma, Giridih, Dhanbad, Bokaro, Ranchi, Gumla, Lohardaga and Purbi Singhbhum. During 1952-2002 the linear interpolated slopes for the pre-monsoon season varied between 0.13 and $1.16 \mathrm{~mm}$ /year during 1952-2002 that showed the absence of negative slopes in the region.
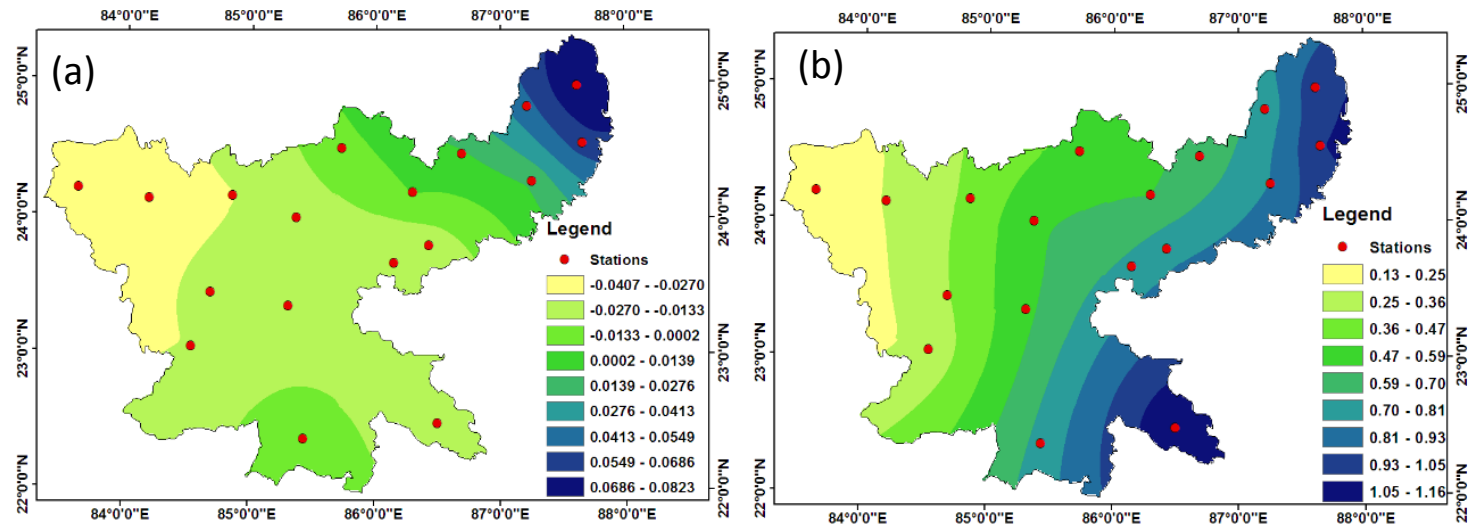

Figure 9. Spatial distribution of temporal change in Pre monsoon rainfall during 1901 to 2002 (a) and from 1952 to 2002 (b).

The interpolated slopes for the post monsoon (Figure 10a,b) precipitation for the period 1901 to 2002 indicated a prevalent positive slope $(0.08$ to $0.30 \mathrm{~mm} /$ year) all over the study area, it showed an increase in rainfall during post-monsoon. After shift point both negative and positive slopes were observed in the study area and it varied between -0.23 and $0.33 \mathrm{~mm} /$ year. The negative slopes were found only at northeastern and southern region of the study area which varied from -0.04 to $-0.24 \mathrm{~mm} /$ year.

For the winter season, negative interpolated slopes were prevalent all over the study area during 1901-2002 (Figure 11a,b). The rainfall magnitude varies from -0.02 to $-0.18 \mathrm{~mm} /$ year during this time period. The maximum negative slopes were observed at Deogarh, Dumka and Dhanbad. After shift point both negative and positive slopes, ranged between -0.24 and $0.12 \mathrm{~mm}$ /year were observed. However, widespread negative slopes $(-0.03$ to $-0.024 \mathrm{~mm} /$ year) were depicted covering most of the state, except for western part of Jharkhand during 1952-2002. 

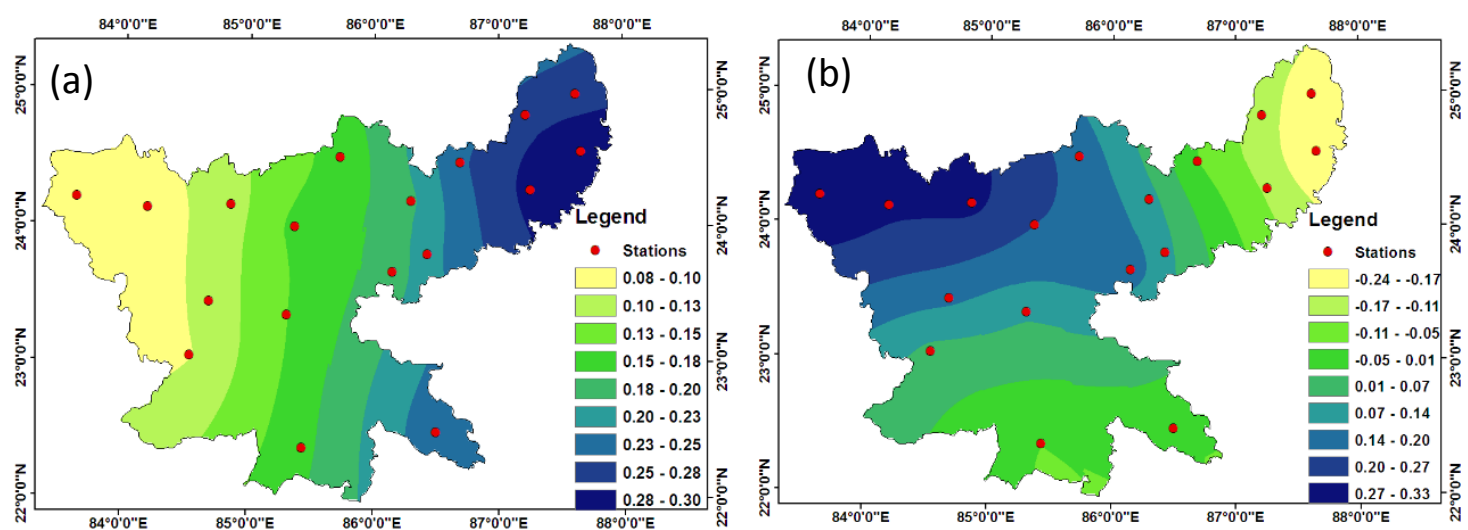

Figure 10. Spatial distribution of temporal change in Post monsoon rainfall during 1901 to 2002 (a) and from 1952 to 2002 (b).
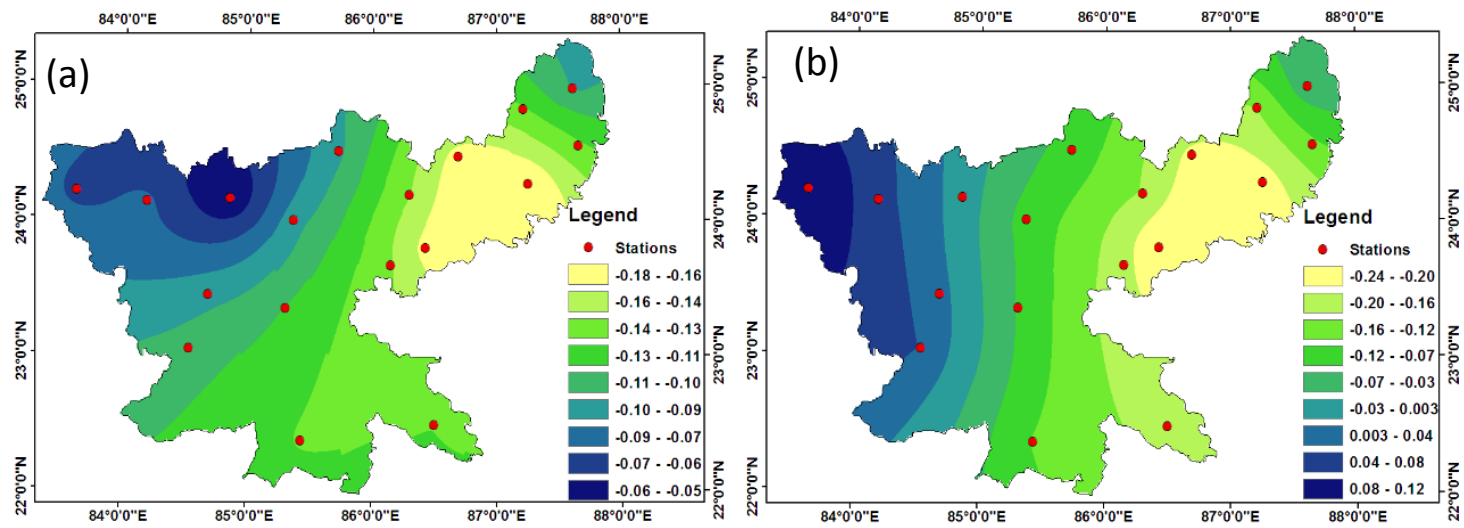

Figure 11. Spatial distribution of temporal change in winter rainfall during 1901 to 2002 (a) and from 1952 to 2002 (b).

\subsection{Precipitation Trends over Entire Jharkhand}

The results of trend analysis of mean annual and seasonal rainfall for whole Jharkhand is demonstrated in Table 7. The results showed statistically significant downward trend in annual and monsoon rainfall. However, insignificant upward trend was observed for pre-monsoon and post-monsoon season rainfall for the entire state. A decline of $14.11 \%$ and $15.65 \%$ was noticed for annual and monsoon season rainfall respectively. The winter season showed statistically insignificant downward trend, with a decline of $19.38 \%$.

Table 7. Mann Kendall and Percent change analysis over entire Jharkhand.

\begin{tabular}{cccccccc}
\hline Time Series & Test Z & $\boldsymbol{\beta}$ & \% Change & Time Series & Test Z & $\boldsymbol{\beta}$ & \% Change \\
\hline Annual & $-2.6^{* *}$ & -1.8 & -14.11 & Post Monsoon & 1.5 & 0.2 & 28.55 \\
Premonsoon & 0.2 & 0.03 & 3.38 & Winter & -0.9 & -0.1 & -19.38 \\
Monsoon & $-2.7^{* *}$ & -1.7 & -15.65 & & & & \\
\hline
\end{tabular}

$* * *$ if trend at $\alpha=0.001$ level of significance $* *$ if trend at $\alpha=0.01$ level of significance ${ }^{*}$ if trend at $\alpha=0.05$ level of significance + if trend at $\alpha=0.1$ level of significance.

\section{Discussion and Conclusions}

In the present study, trends for annual and seasonal rainfall series were analyzed for Jharkhand during the period 1901-2002 using India water portal rainfall data. The western part of Jharkhand experiences lower rainfall as compared to eastern Jharkhand. The retreating monsoon enters from 
the eastern zone, so it experiences higher rainfall. Coefficient of variation was found higher in the western region of the Jharkhand state. Autocorrelation was absent in the dataset and the results of the trend analysis (Mann-Kendall) showed a downward trend of rainfall in almost over all stations for annual, monsoon and winter season. The results of Mann-Kendall were supported with interpolated maps of linear regression slope values. The slope of the downward trends in annual precipitation ranged between $0.25 \mathrm{~mm}$ per year (at Purbi Singhbhum station in Northeastern zone) to $2.49 \mathrm{~mm}$ per year (at Godda station in Southeastern zone) as per Sen's slope values. The downward trend in seasonal rainfall will have a more pronounced effect on agricultural activities in the area. It may affect the growth phase of the Kharif crops (May-October) and irrigation is mandatory to tackle the moisture stress. Mann Whitney Pettit and cumulative deviations test results found most probable year of change in the state to be year 1951. There was an upward trend in the state during the period 1901-1951(before change point), which got reversed during the period 1952-2002 (after change point). For whole Jharkhand a downward trend in annual rainfall was noticed in the study.

Sathiyamoorthy and Rao et al found a reduction in strength of Tropical Easterly Jet Stream during monsoon in the recent five decades, which are responsible for the formation of monsoon depressions during the southwest monsoon season, and that are the important rain bearing systems during the southwest monsoon season [31,32]. The decrease in frequency of cyclonic storms over Indian seas during 1981-1997 have been reported by Ray and Srivastava [33]. These weather systems declining frequency may be one of the probable reasons for the decline in rainfall over the area.

From the study, it is concluded that annual and monsoon rainfall decreased significantly in Jharkhand during the period 1901-2002. If this downward trend in rainfall persists, it would badly impact the economy of the state. There is a need to integrate the changing climate in the planning and management of water resources of the state.

Acknowledgments: The authors are thankful to India water portal for providing the essential data required for the present study. Sincere thanks to Arun Kumar Taxak (Research scholar, Indian Institute of Technology, Roorkee) for his help in data handling. Authors are sincerely grateful to Amit Ghosh (PhD. student, Jadavpur University) for his earnest help in using R software. Finally, we would like to thank the anonymous reviewers for their valuable comments and suggestions which helped us on improving this paper.

Author Contributions: The design of study, data collection and data analysis has been done by Shonam Sharma and Prasoon Kumar Singh contributed to the interpretation part of the study. While the manuscript writing has been done by both the authors.

Conflicts of Interest: The authors declare no conflict of interest.

\section{References}

1. Cruz, R.; Lasco, R.; Pulhin, J.; Pulhin, F.; Garcia, K. Climate Change Impact on Water Resources in Pantabangan Watershed, Philippines; AIACC Final Technical Report; The International Start Secreteriat: Washington, DC, USA, 2006; pp. 9-107.

2. Hu, Z.Z.; Yang, S.; Wu, R. Long-term climate variations in China and global warming signals. J. Geophys. Res. Atmos. 2003, 108. [CrossRef]

3. Peterson, B.J.; Holmes, R.M.; McClelland, J.W.; Vörösmarty, C.J.; Lammers, R.B.; Shiklomanov, A.I.; Shiklomanov, I.A.; Rahmstorf, S. Increasing river discharge to the Arctic Ocean. Science 2002, 298, 2171-2173. [CrossRef] [PubMed]

4. Dore, M.H. Climate change and changes in global precipitation patterns: What do we know? Environ. Int. 2005, 31, 1167-1181. [CrossRef] [PubMed]

5. Stocker, T.F.; Qin, D.; Plattner, G.-K.; Tignor, M.; Allen, S.K.; Boschung, J.; Nauels, A.; Xia, Y.; Bex, V.; Midgley, P.M. Climate Change 2013: The Physical Science Basis; Cambridge University Press: Cambridge, UK; New York, NY, USA, 2014.

6. Jones, P.; Hulme, M. Calculating regional climatic time series for temperature and precipitation: Methods and illustrations. Int. J. Climatol. 1996, 16, 361-377. [CrossRef]

7. Hulme, M.; Osborn, T.J.; Johns, T.C. Precipitation sensitivity to global warming: Comparison of observations with HadCM2 simulations. Geophys. Res. Lett. 1998, 25, 3379-3382. [CrossRef] 
8. Nicholls, N. El nino-southern oscillation and rainfall variability. J. Clim. 1988, 1, 418-421. [CrossRef]

9. Clark, C.O.; Cole, J.E.; Webster, P.J. Indian Ocean SST and Indian summer rainfall: Predictive relationships and their decadal variability. J. Clim. 2000, 13, 2503-2519. [CrossRef]

10. Times of India. Available online: http://timesofindia.indiatimes.com/india/40-of-India-still-banks-onmonsoon-for-agriculture/articleshow / 47115057.cms (accessed on 7 February 2017).

11. Guhathakurta, P.; Rajeevan, M. Trends in the rainfall pattern over India. Int. J. Climatol. 2008, 28, 1453-1470. [CrossRef]

12. Rotstayn, L.D.; Lohmann, U. Tropical rainfall trends and the indirect aerosol effect. J. Clim. 2002, 15, 2103-2116. [CrossRef]

13. Krishnakumar, K.N.; Prasada Rao, G.S.L.H.V.; Gopakumar, C.S. Rainfall trends in twentieth century over Kerala, India. Atmos. Environ. 2009, 43, 1940-1944. [CrossRef]

14. Subash, N.; Singh, S.S.; Priya, N. Extreme rainfall indices and its impact on rice productivity-A case study over sub-humid climatic environment. Agric. Water Manag. 2011, 98, 1373-1387. [CrossRef]

15. Patra, J.P.; Mishra, A.; Singh, R.; Raghuwanshi, N. Detecting rainfall trends in twentieth century (1871-2006) over Orissa state, India. Clim. Chang. 2012, 111, 801-817. [CrossRef]

16. Basistha, A.; Arya, D.; Goel, N. Analysis of historical changes in rainfall in the Indian Himalayas. Int. J. Climatol. 2009, 29, 555-572. [CrossRef]

17. Kumar, V.; Jain, S.K. Trends in rainfall amount and number of rainy days in river basins of India (1951-2004). Hydrol. Res. 2011, 42, 290-306. [CrossRef]

18. Meshram, S.G.; Singh, V.P.; Meshram, C. Long-term trend and variability of precipitation in Chhattisgarh state, India. Theor. Appl. Climatol. 2016. [CrossRef]

19. Duhan, D.; Pandey, A. Statistical analysis of long term spatial and temporal trends of precipitation during 1901-2002 at Madhya Pradesh, India. Atmos. Res. 2013, 122, 136-149. [CrossRef]

20. Barsugli, J.; Anderson, C.; Smith, J.; Vogel, J. Options for Improving Climate Modeling to Assist Water Utility Planning for Climate Change; Water Utility Climate Alliance: Clearwater, FL, USA, 2009.

21. Brekke, L.D. Climate Change and Water Resources Management: A Federal Perspective; DIANE Publishing: Darby, PA, USA, 2009.

22. Agricultural Drought Assessment Report. Available online: http://bhuvan.nrsc.gov.in/bhuvan/PDF/ NADAMS_July12_Report.pdf (accessed on 20 August 2016).

23. India Water Portal. Available online: http://www.indiawaterportal.org/metdata (accessed on 10 January 2016).

24. Pettitt, A. A non-parametric approach to the change-point problem. Appl. Stat. 1979, 28, 126-135. [CrossRef]

25. Buishand, T.A. Some methods for testing the homogeneity of rainfall records. J. Hydrol. 1982, 58, 11-27. [CrossRef]

26. Anderson, R.L. Distribution of the serial correlation coefficient. Ann. Math. Stat. 1942, 13, 1-13. [CrossRef]

27. Sen, P.K. Estimates of the regression coefficient based on Kendall's Tau. J. Am. Stat. Assoc. 1968, 63, 1379-1389. [CrossRef]

28. Cleveland, W.S. Robust locally weighted regression and smoothing scatterplots. J. Am. Stat. Assoc. 1979, 74, 829-836. [CrossRef]

29. Cleveland, W.S.; Grosse, E. Computational methods for local regression. Stat. Comput. 1991, 1, 47-62. [CrossRef]

30. Helsel, D.R.; Hirsch, R.M. Statistical Methods in Water Resources; US Geological Survey: Reston, VA, USA, 2002.

31. Sathiyamoorthy, V. Large scale reduction in the size of the tropical easterly jet. Geophys. Res. Lett. 2005, 32. [CrossRef]

32. Rao, B.; Rao, D.; Rao, V.B. Decreasing trend in the strength of tropical easterly jet during the Asian summer monsoon season and the number of tropical cyclonic systems over Bay of Bengal. Geophys. Res. Lett. 2004, 31, L14103. [CrossRef]

33. Ray, K.S.; Srivastava, A. Is there any change in extreme events like heavy rainfall? Curr. Sci. 2000, 79, $155-158$.

(C) 2017 by the authors. Licensee MDPI, Basel, Switzerland. This article is an open access article distributed under the terms and conditions of the Creative Commons Attribution (CC BY) license (http:/ / creativecommons.org/licenses/by/4.0/). 